\title{
The effect of songs on vocabulary retention of preschool young English language learners
}

\author{
Madani, Davood $\triangle$ \\ English Department, Islamic Azad University, Khomein Branch, Khomein, Iran (dr.madanilinguist@gmail.com) \\ Mahmoodi Nasrabadi, Mahboobeh \\ English Department, Islamic Azad University, Khomein Branch, Khomein, Iran (mmahmoodi9703@ gmail.com)
}

Received: 25 June 2016

Accepted: 14 July 2016

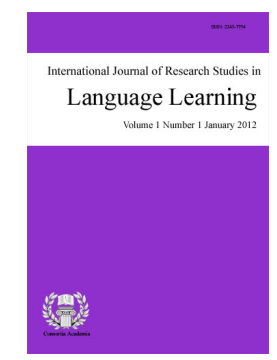

ISSN: 2243-7754 Online ISSN: 2243-7762

OPEN ACCESS

\section{Abstract}

The present study was an attempt to investigate the effectiveness of teaching English vocabulary through song to preschool young English Language Learners in Aligoodarz, Iran. The participants of the study consisted of 103 preschool young learners, who were divided into two groups of experimental group and control group. The experimental groups were consisted of 62 young learners and the control groups were consisted of 51 young learners at the age of six. The experimental groups were instructed using song and the control groups were instructed using non-song methods. Twenty sessions were spent working on teaching vocabulary for each group. Before starting the treatment, an interview was done as a pretest by the teacher to confirm that learners did not have any prior knowledge of English. After finishing the treatment, the post-test was administered by the teacher to measure the amount of learning vocabulary items in each group. The data then was analyzed using the SPSS. The findings revealed that the experimental group improved significantly in terms of vocabulary retention compared to control group.

Keywords: song; vocabulary retention; English language learners 


\section{The effect of songs on vocabulary retention of preschool young English language learners}

\section{Introduction}

One of the major problems that learners encounter in learning any languages is how to memorize vocabulary and gain master over it. Despite the fact that vocabulary is a critical part of any language, most studies have only focused on other aspects of language learning. Vocabulary learning is an intrinsic part of both language teaching and language learning. If learners are not able to gain master over vocabulary in learning any language, they will definitely face problems in the steps of learning that particular language.

It is teachers' responsibility to create an effective atmosphere for learners and help them learn the second language words efficiently. Therefore, studying different strategies and procedures that teachers should make use of them in the process of language teaching is an important issue. Today, teachers use a variety of methods to increase the results of teaching instruction. They have always been seeking to find a new method which has more attractive force for learners. For this purpose, song is an ideal means through which L2 lexicon could be presented to the learners without explicit teaching. It can be used as an aid for teaching vocabulary to young learners because the nature of young learners emphasizes that they receive great energy with listening to song. Song may be a vehicle through which one is able to maximize the involvement load. We can apply the tenet of Involvement Load Hypothesis, which suggests that words are better learned when learners do more with them on both the cognitive and motivational levels (Hulstijn \& Laufer, 2001).

Research on psycholinguistics reveals that songs can activate language acquisition and learning in both hemispheres of the human brain (Carroll, 2000; Larsen-freeman \& Long, 2000, Williams \& Burden, 1997). The human brain is divided into two hemispheres.The left hemisphere is responsible for expressing the thoughts in oral or written words. In other word, this hemisphere stores all the concepts that afterward are translated into words. The right hemisphere, on the other hand, is specialized in the non-verbal faculties, such as feeling, emotion, and special artistic and musical abilities. The Song enters the human brain from the left ear to the right hemisphere in a rather different way from our speech and thus can stimulate language learning in the right hemisphere. In this regard, Gardner (1985) in his history of multiple intelligences claims that all human beings have musical intelligence and that the use of music is very positive in language learning because it can open an opportunity for learners who have a strong right brain orientation. Guglielmino (1986) states that "songs bridge the (brain's) hemispheres strengthening, retention through a complementary function as the right hemisphere learns the melody, the left the words" (p. 20). Anton (1990) found that "when a learning activity combines both left and right hemispheres simultaneously engaged in a particular activity, an ideal learning situation is established and the most productive learning occurs" (p. 1170).

Activities which engage both sides of the brain at the same time, such as playing an instrument or singing ,cause the brain to be more capable of processing information. Another reason that song may play a role in second language lexical retention is in the simple fact that when melody is repeated across verses, it allows listeners to become more familiar with the melody so quickly. Also during early and middle childhood, there is a close link between children's vocabulary knowledge and their ability to retain new phonological information for a short period of time (Gathercole \& Baddeley, 1989; Gathercole \& Adams, 1994).

The present situation for learning English in our classes is mainly boring for most children, causing all of them to have many problems in learning English and more specifically in remembering the words they have learned. Therefore, this study is focused on trying to discover how to facilitate vocabulary learning and retention by using songs. In the present study, the aim is to clarify the effect of using song in retention and learning of vocabulary in preschool young English language learners. 
The effect of songs on vocabulary retention of preschool young English language learners

In the view of the facts stated above, the research questions addressed in this study are as follows:

$>$ Does the use of song have any effects on vocabulary retention of preschool young English language learners?

$>$ Does the use of song have any effects on vocabulary learning of preschool young English language learners?

$>$ Does gender of young EFL learners play any significant role in vocabulary learning and retention?

\section{Literature Review}

It appears that second language (L2) vocabulary learning is not welcomed by many students because they have problems not only in memorizing the meaning, pronunciation, and spelling of L2 words but also in recalling and remembering them (Thornbury, 2002). It can be said that limited vocabulary is a kind of imperfection. For understanding what someone hears and reads and also to communicate effectively with others, vocabulary breadth is so crucial (Shoebottom, 2013).Thus, it is necessary to improve the techniques of teaching L2 vocabulary to students in teachers and to break the routine that has made the students bored and discouraged them to learn vocabularies. One of the techniques that L2 teachers can use to promote students' interests and motivations in learning L2 vocabulary is using song (Medina, 1993; Murphey, 1992).

Salcedo (2010) examined the effects of song in the foreign language classroom on the text recall and involuntary rehearsal. The relationship between language and song/music was also investigated by Murphy. He introduces the notion song-stuck-in-my-head (S.SIMH). Other studies have investigated the effects of the use of songs on lexical learning within school projects (Legg, 2009; Li \& Brand, 2009).There are a plethora of educational literature and web-based materials discussing the use of songs in the ESL classroom (Kramer, 2001). Mora (2000) believed that music and language should be often used in the teaching of English as a foreign language. Songs introduce the repetition of words, phrases, and such repetition enables the brain to remember a learned context.

According to Yuliana (2003) singing a song is enjoyable for learners and because words are repeated several times, learners are able to memorize them easily. Another feature of songs is that they are learnt by heart and as a result lead to learners' development. Making use of the music in the ELT is not a new task. Bartle (1962) and Richards (1969), Jolly (1975), and other scholars have studied the effects of music on language learning because of its linguistic, and motivational advantages (as cited in Engh, 2013). There are a number of studies which prove strongly the positive effectiveness of music on various language areas. Based on research using background music to aid verbal phrase recall, Mora (2000) asserts that songs have a positive outcome on the students' language acquisition and that lexical patterns stored in the long-term musical memory can be retrieved with ease at a later date for mental rehearsal, memorization or during oral interaction. The use of rhythm and rhyme to assist auditory recall as well as the multimodal combination of rhythm has also been studied. Researchers have shown that music facilitates learning of a foreign language (Keskin, 2011). Salcedo (2002) has shown in her study that there is a significant increase in text recall when that text is learned through the use of songs. Her research has also shown that students who hear texts as music report a higher occurrence of involuntary mental rehearsal than the students who only hear spoken texts. Salcedo (2010) examined the effects of songs in the foreign language classroom on text recall and involuntary rehearsal. He wanted to explore whether English native speakers learning a foreign language can benefit from integrating music into the curriculum. Students' text recall was measured after listening to songs and text passages. The results showed that recall was better in the song condition than text passage.

This research providing support to educators who wish to integrate music and musical instruction into their early language teaching and literacy programs in schools. It also tries to explore the effectiveness of utilizing songs/music in retention of new vocabulary when applied to preschool young English language learners. 


\section{Method}

\subsection{Research Design}

In this study experimental design was employed to investigate the research question. To find the effect of song on vocabulary learning and retention of Aligoodarz preschool young English language learners, the researcher performed song in the experimental group for teaching new vocabularies whereas for the control groups, song was not performed. Before starting any treatment, an interview was done as a pretest for affirming the English background knowledge of learners. The results of the interview (pretest) showed that learners were homogenized since they didn't have any background knowledge of English, therefore, they were considered to be at the true beginner level.

The experimental groups received the treatment which included performing songs while the control group did not receive such treatment. The teacher's observation during the class and the learners' answers in the interview after the treatment were considered as the posttest for this study. Ten days after conducting the posttest, the researcher repeated the same interview as a delay posttest to test the retention of learners. The pretest, posttest and delayed posttest were assigned in a way to be parallel.

\subsection{Research setting}

This study was conducted in two preschool centers, which were situated in Aligoodarz, Iran. One of these centers was a private institute while the other was a public school. The approximate number of learners at these centers was 240 learners which were divided in two shifts. The morning shift was selected for the purpose of this study.

\subsection{Participants}

The number of the participants attending the present of the study was 112 who were six-years-old preschool young learners who were divided into two groups: experimental group consisted of 62 participants while the control group included 50 learners. All of the participants were attending preschool classes at Kooshan Instifute and Yeki Yedooneh preschool center in Alligoodarz.

\subsection{Material}

The main book which was taught in this study was Pocket1 by Barbara and Herrera (2009) and songs for the experimental group were selected from this book and supper simple songs. The vocabulary items were selected from the songs. These selected vocabulary items were taught to the experimental group through performing songs. The selected songs utilized simple and pleasant songs and contained topics that were interesting for children.

\subsection{Instrument}

At the beginning of the study, the researcher administered a preliminary English interview as a proficiency test to make sure of the homogeneity of the participants. By this interview, which functioned as the pretest, it was confirmed that the learners did not have any background knowledge of English and they were at the same level. After twenty sessions of the treatment, they were assessed with the similar interview which functioned as the posttest to measure their vocabulary learning and compare the possible effect of songs on learning English vocabulary. After ten days, the researcher repeated the same interview (as the delayed posttest) to evaluate the retention of vocabulary learning in the preschool young learners. 


\section{Result and discussion}

The analysis of data was done by using statistical software SPSS 23 in two levels, descriptive and inferential. Based on research questions, frequency distribution was performed for the descriptive level, and t-test was performed for the inferential level.

\subsection{Gender Distribution}

Sample gender of the present study is indicated in the Table 1. Of the 112 samples, $64(57.1 \%)$ were male and $48(42.9 \%)$ were female.

\section{Table 1}

Gender Distribution

\begin{tabular}{llcc}
\hline & & Frequency & Percentage \\
\hline Gender & Male & 64 & $57.1 \%$ \\
& Female & 48 & $42.9 \%$ \\
Total & & 112 & $100 \%$ \\
\hline
\end{tabular}

\subsection{Gender distribution in experimental and control groups}

In Table 2, the number of children in experimental and control groups as well as the distribution of gender is indicated.

\section{Table 2}

The number of children in experimental and control groups considering the gender distribution

\begin{tabular}{lccc} 
& \multicolumn{2}{c}{ Groups } & \multirow{2}{*}{ Total } \\
\cline { 2 - 3 } & Experimental & Control & \\
\hline Male & 39 & 25 & 64 \\
Female & 23 & 25 & 48 \\
Total & 62 & 50 & 112 \\
\hline
\end{tabular}

\subsection{Descriptive information of vocabulary learning scores}

In Table 3, descriptive information including mean and standard deviation for vocabulary learning scores in experimental and control groups is indicated.

\section{Table 3}

Descriptive statistics for vocabulary learning scores by gender and method of teaching

\begin{tabular}{lcccccc}
\hline \multirow{2}{*}{ Method of teaching } & \multicolumn{3}{c}{$\begin{array}{c}\text { Mean } \\
\text { gender }\end{array}$} & \multicolumn{3}{c}{$\begin{array}{c}\text { SD } \\
\text { gender }\end{array}$} \\
\cline { 2 - 7 } & $(\mathrm{M})$ & $(\mathrm{F})$ & Total & $(\mathrm{M})$ & $(\mathrm{F})$ & Total \\
\hline Control & 9.13 & 9.00 & 9.08 & 6.161 & 6.216 & 6.131 \\
Experimental & 11.28 & 13.56 & 12.42 & 4.937 & 5.994 & 5.555 \\
Total & 9.97 & 11.38 & 10.57 & 5.771 & 6.460 & 6.088 \\
\hline
\end{tabular}

As shown in Table 3, it was observed that in general, regardless of gender, the mean scores of control group is 9.08 and it is less than the mean scores of the experimental group (12.42). Such difference is also seen in the mean scores of males and females. The mean scores of experimental group is higher than the mean scores of the control group for both male and female learners. And the mean scores of females are higher than the mean scores of males in experimental group, which indicates that females outperformed the males. The values of standard deviation indicate that variability of vocabulary learning scores are almost the same for both groups. 
Madani, D., \& Mahmoodi Nasrabadi, M.

\subsection{Descriptive information of vocabulary retention scores}

In table 4, descriptive information consisting mean and standard deviation for vocabulary retention scores in two groups is presented.

\section{Table 4}

Descriptive statistics for vocabulary retention scores by gender and method of teaching

\begin{tabular}{lcccccc}
\hline \multirow{2}{*}{\multicolumn{1}{c}{ Method of teaching }} & \multicolumn{3}{c}{$\begin{array}{c}\text { Mean } \\
\text { gender }\end{array}$} & \multicolumn{3}{c}{$\begin{array}{c}\text { SD } \\
\text { gender }\end{array}$} \\
\cline { 2 - 7 } & $\mathrm{M}$ & $\mathrm{F}$ & Total & $\mathrm{M}$ & $\mathrm{F}$ & Total \\
\hline Control Group & 8.54 & 7.83 & 8.27 & 5.591 & 6.293 & 5.820 \\
Experimental Group & 9.84 & 13.08 & 11.46 & 5.677 & 6.317 & 6.165 \\
Total & 9.05 & 10.56 & 9.70 & 5.616 & 6.779 & 6.158 \\
\hline
\end{tabular}

As shown in Table 4, it is observed that in general, and regardless of gender, the mean scores of control group is 8.27 and it is less than mean scores of experimental group (11.46). Such difference is also seen in the mean scores of male and female groups. Moreover, regardless of grouping related to methodology, the mean scores of vocabulary retention is 10.56 for females which is higher than the mean scores of males (9.05). It is also indicated that, in general, scores of female learners are better than males' scores. Although for the control group, the mean scores of females (7.83) was less than the mean scores of males (8.54). The values of standard deviation indicate that variability of vocabulary learning scores is almost the same for all groups.

With regards to mean scores of 'vocabulary learning' and 'vocabulary retention', as shown in Tables 3 and 4, it is observed that the scores of females in experimental group is better than males' scores in this group. Table 5 shows the results of One- Sample Kolmogorov- Smirnov Test which checks the normality of variables.

\section{Table 5}

One-Sample Kolmogorov-Smirnov Test

\begin{tabular}{|c|c|c|c|c|c|c|c|}
\hline & \multirow{2}{*}{ group } & \multirow{2}{*}{ gender } & \multirow{2}{*}{$\mathrm{N}$} & \multicolumn{2}{|c|}{ Normal Parameters } & \multirow{2}{*}{ Test Statistic } & \multirow{2}{*}{ Sig. } \\
\hline & & & & Mean & SD & & \\
\hline \multirow{4}{*}{ 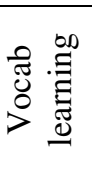 } & Control & $\mathrm{M}$ & 39 & 9.13 & 6.161 & 0.163 & .051 \\
\hline & & $\mathrm{F}$ & 23 & 9.00 & 6.216 & 0.181 & .050 \\
\hline & Experimental & M & 25 & 11.28 & 4.937 & 0.118 & .200 \\
\hline & & $\mathrm{F}$ & 25 & 13.56 & 5.994 & 0.197 & .073 \\
\hline \multirow{4}{*}{ 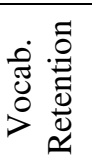 } & Control & $\mathrm{M}$ & 39 & 8.54 & 5.591 & 0.173 & .065 \\
\hline & & $\mathrm{F}$ & 23 & 7.83 & 6.293 & 0.171 & .081 \\
\hline & Experimental & $\mathrm{M}$ & 25 & 9.84 & 5.677 & 0.111 & .200 \\
\hline & & $\mathrm{F}$ & 25 & 13.08 & 6.317 & 0.182 & .032 \\
\hline
\end{tabular}

\subsection{Does the use of song have any effect on preschool young learners'vocabulary learning?}

To evaluate the effectiveness of using song in vocabulary learning process, the obtained scores of experimental and control groups are compared with each other. Descriptive information of obtained scores are shown in Table 6:

Table 6

Descriptive statistics for vocabulary learning scores by method of teaching

\begin{tabular}{lcccc}
\hline & Method of Teaching & N & Mean & SD \\
\hline Vocab Learning & Control Group & 62 & 9.08 & 6.131 \\
& Experimental Group & 50 & 12.42 & 5.555 \\
\hline
\end{tabular}

According to the results of Table 6, it is observed that the mean scores in vocabulary learning for control 
The effect of songs on vocabulary retention of preschool young English language learners

group is 9.08 , while it is $\mathbf{1 2 . 4 2}$ for the experimental group. On the other hand, according to standard deviation values for both groups, it can be said that variability of scores are equal in both groups. Therefore, according to the mean scores in both groups, there is a difference between two groups in terms of vocabulary learning. To determine the significance of difference between the two groups, sample t-test was run. The results can be seen in Table 7.

Table 7

" $T$ " ratio for the difference in the means of experimental and control groups

\begin{tabular}{|c|c|c|c|c|c|c|}
\hline & \multicolumn{6}{|c|}{ t-test for Equality of Means } \\
\hline & \multirow[t]{2}{*}{$\mathrm{t}$} & \multirow[t]{2}{*}{ df } & \multirow[t]{2}{*}{ Sig. } & \multirow[t]{2}{*}{ Mean Difference } & \multicolumn{2}{|c|}{$\begin{array}{l}95 \% \text { Confidence Interval of } \\
\text { the Difference }\end{array}$} \\
\hline & & & & & Lower & Upper \\
\hline vocab. learning & -2.987 & 110 & .003 & -3.339 & -5.555 & -1.124 \\
\hline
\end{tabular}

The results of Table 7 indicates that the observed difference between the two groups is significant at the 5\% level (sig is less than 0.05). Thus, according to the mean scores value in Table 6 , it can be said that experimental group's scores are higher than the scores of control group and this difference is meaningful and significant. As a result, according to the results of the study, performing song had a positive effect on vocabulary learning of young EFL learners.

\subsection{Does the use of song have any effect on preschool young learners'vocabulary retention?}

To answer the second research question, the scores related to retention process of both experimental and control groups were compared. Descriptive information of obtained scores is shown in Table 8:

Table 8

Descriptive statistics for vocabulary learning scores by method of teaching

\begin{tabular}{llccc}
\hline & Method of Teaching & N & Mean & SD \\
\hline Vocab Retention & Control Group & 62 & 8.27 & 5.820 \\
& Experimental Group & 50 & 11.46 & 6.165 \\
\hline
\end{tabular}

According to the results of Table 8 , it is observed that the mean scores in vocabulary retention for control group is 8.27 , while it is 11.46 for the experimental group. On the other hand, according to standard deviation values for both groups, it can be said that the variability of scores are equal in both groups. Therefore, according to the mean scores in two groups, there is difference between two groups in vocabulary retention. To determine the significance of difference between the two groups, t-test was run. The results of t-test can be seen in Table 9 .

\section{Table 9}

" $T$ " ratio for the difference in means of experimental and control groups on vocab retention

\begin{tabular}{|c|c|c|c|c|c|c|}
\hline & \multicolumn{6}{|c|}{ t-test for Equality of Means } \\
\hline & \multirow[t]{2}{*}{$\mathrm{t}$} & \multirow[t]{2}{*}{ df } & \multirow[t]{2}{*}{ Sig. } & \multirow[t]{2}{*}{ Mean Difference } & \multicolumn{2}{|c|}{$\begin{array}{l}\text { 95\% Confidence Interval of the } \\
\text { Difference }\end{array}$} \\
\hline & & & & & Lower & Upper \\
\hline vocab retention & -2.805 & 110 & .006 & -3.186 & -5.437 & -.935 \\
\hline
\end{tabular}

The results of Table 9 indicates that the observed difference between the two groups is significant at the 5\% level. Thus, according to the mean scores value shown in Table 8, it can be concluded that experimental group's scores are higher than control group's scores and this difference is meaningful and significant. As a result, based on sample, performing song in teaching improves the vocabulary retention in young EFL learners.

\subsection{Does gender of young EFL learners play any significant role in vocabulary learning and retention?}

Descriptive information of obtained scores by the two groups is shown in Table 10: 
Madani, D., \& Mahmoodi Nasrabadi, M.

\section{Table 10}

Descriptive statistics for vocab retention scores by method of teaching and Gender

\begin{tabular}{lllcc}
\hline Gender & Method of Teaching & N & Mean & SD \\
\hline (M) & Control Group & 39 & 8.54 & 5.591 \\
& Experimental Group & 25 & 9.84 & 5.677 \\
\hline (F) & Control Group & 23 & 7.83 & 6.293 \\
& Experimental Group & 25 & 13.08 & 6.317 \\
\hline
\end{tabular}

According to the results of Table 10, it is observed that the rate of vocabulary retention for experimental group is higher than the control group for both male and female learners. Therefore, the mean scores of males in control group is equal to 8.54 which is less than that of the experimental group (9.84). The mean score of females is equal to 7.83 for the control group and 13.08 for the experimental group.

Based on the mean scores observed in both groups and the difference observed between them, there is not any meaningful differences between the two groups (experimental and control groups) for male learners, while for females, the difference is observed. To determine the significance of the difference between them, t-test was run. The results can be seen in Table 11 .

\section{Table 11}

" $T$ " ratio for the difference in means of experimental and control group on vocab retention by gender

\begin{tabular}{|c|c|c|c|c|c|c|}
\hline \multirow{3}{*}{ Gender } & \multicolumn{6}{|c|}{ t-test for Equality of Means } \\
\hline & \multirow{2}{*}{$\mathrm{t}$} & \multirow{2}{*}{ df } & \multirow{2}{*}{ Sig. } & \multirow{2}{*}{ Mean Difference } & \multicolumn{2}{|c|}{$95 \%$ Confidence Interval of the Difference } \\
\hline & & & & & Lower & Upper \\
\hline (M) & -.903 & 62 & .370 & -1.302 & -4.182 & 1.579 \\
\hline (F) & -2.884 & 46 & .006 & -5.254 & -8.921 & -1.587 \\
\hline
\end{tabular}

Table 11 indicates that there is no meaningful difference between scores in experimental and control groups for male learners ( $\mathrm{sig}$ is more than 0.05). While, there is meaningful differences between the two groups in terms of vocabulary retention (sig is less than 0.05 ). Therefore, according to the mean scores of each group, it can be said that for females, rate of vocabulary retention in experimental group is meaningfully higher than that of control group. But for males, there is no meaningful difference in vocabulary retention. Table 12 shows the results of t-test.

Table 12

" $T$ " ratio for the difference in means of males and females on vocab retention by method of teaching

\begin{tabular}{|c|c|c|c|c|c|c|}
\hline \multirow{3}{*}{$\begin{array}{l}\text { Methods } \\
\text { of Teaching }\end{array}$} & \multicolumn{6}{|c|}{ t-test for Equality of Means } \\
\hline & \multirow[t]{2}{*}{$\mathrm{t}$} & \multirow[t]{2}{*}{ df } & \multirow[t]{2}{*}{ Sig. } & \multirow[t]{2}{*}{ Mean Difference } & \multicolumn{2}{|c|}{$\begin{array}{l}\text { 95\% Confidence Interval of the } \\
\text { Difference }\end{array}$} \\
\hline & & & & & Lower & Upper \\
\hline $\begin{array}{l}\text { Control } \\
\text { Group }\end{array}$ & 0.463 & 60 & 0.645 & 0.712 & -2.368 & 3.793 \\
\hline $\begin{array}{l}\text { Experimental } \\
\text { Group }\end{array}$ & -1.907 & 48 & 0.062 & -3.240 & -6.655 & 0.175 \\
\hline
\end{tabular}

According to the results shown in Table 12, it is observed that there is no meaningful differences between female and male learners in vocabulary retention in the experimental and control groups (in both groups sig is higher than 0.05).

\section{Discussion and Conclusion}

If more awareness is assigned for teaching vocabulary, lexical items will be retained better and more effectively over longer time periods. The work of Laufer and Hulstijn (2001) provides convincing evidence that, in fact, classroom tasks that place greater cognitive demands on participants and allow them to do more with 
The effect of songs on vocabulary retention of preschool young English language learners

lexical items lead to better learning outcomes in second language learners in terms of their retention and knowledge of those lexical items. Employing music and songs in English class is not a replacement to other methods, however, they can be considered as an acceptable material for classroom instruction (Salcedo, 2002). We can employ a song with enough resilience to stick in mind long enough for learners to experience success with certain language structures, learn features of the target culture, or achieve listening enjoyment, as Salcedo (2002) states.

In this study, the experimental group in which more emphasis was placed on retention of lexical items by performing song, outperformed the control group in the posttest. The results indicate that teaching new vocabulary through song has significantly increased learners' achievement in English vocabulary learning and positive attitudes toward the musical instruction and the retention of new vocabulary of the learners in the musical-mode, experimental group, compared to the nonmusical-mode, control group. Interestingly, musical-mode group (experimental group) learners obtained higher scores whether immediately after the instruction or after the interval. In terms of attitudes towards English learning, the musical-mode group had more positive attitude towards English learning and showed greater degree of confidence as well. Therefore, performing song is a good method for attracting learners' attention and making a good atmosphere for learning English.

\subsection{Pedagogical Implication}

The results obtained in this study would suggest a number of implications which can be useful for teachers, and language practitioners in EFL context. The findings with the nature to perform song and musical mode in our classroom contexts for young learners are required to be applied in our syllabus and EFL textbooks. Implications arising from this study suggest that teachers, syllabus designers and material developers should take into account several important principles of language learning such as learner needs and interests, learner involvement and this is through including interactive activities that provide students with a sense of achievement and encourage them in the process of language learning and how to approach it more effectively.

\section{References}

Anton, R. J. (1990). Combining singing and psychology. Hispania, 73(4), 1166-1170. http://dx.doi.org/10.2307/344326

Bartle, G. (1962). Music in the language classroom. Canadian Modern Language Review, 19(1), 11-13.

Carroll, D. W. (2000). Psychology of language ( $3^{\text {rd }}$ ed.). Beijing: Foreign Language Teaching and Research Press.

Engh, D. (2013). Why use music in English language learning? A survey of the literature. Journal of English Language Teaching, 6, 12-25. http://dx.doi.org/10.5539/elt.v6n2p113

Gardner, H. (1985). Frames of mind: The theory of multiple intelligences. New York: Basic Books.

Gathercole, S. E., \& Adams, A. (1994). Children's phonological working memory: Contributions of long-term knowledge and rehearsal. Journal of Memory and Language, 33, 672-688. http://dx.doi.org/10.1006/jmla.1994.1032

Gathercole, S. E., \& Baddeley, A. D. (1989). Evaluation of the role of phonological STM in the development of vocabulary in children: a longitudinal study. Journal of Memory and Language, 28, 200-213. http://dx.doi.org/10.1016/0749-596X(89)90044-2

Guglielmino, L. M. (1986). The affective edge: Using songs and music in ESL instruction. Adult Literacy and Basic Education, 10(1), 19-26.

Hulstijn, J., \& Laufer, B. (2001). Some empirical evidence for the involvement load hypothesis in vocabulary acquisition. Language Learning, 51, 539-558. http://dx.doi.org/10.1111/0023-8333.00164

Jolly, Y. S. (1975). The use of songs in teaching foreign languages. The Modern Language Journal, 59(1/2), 11-14. http://dx.doi.org/10.1111/j.1540-4781.1975.tb03618.x

Keskin, F. (2011). Using songs as audio materials in teaching Turkish as a foreign. Turkish Online Journal of 
Madani, D., \& Mahmoodi Nasrabadi, M.

Educational Technology, 4, 378-383.

Kramer, D. (2001). A blueprint for teaching foreign languages and cultures through music in the classroom and on the web. ADFL Bulletin, 33(1), 29-35. http://dx.doi.org/10.1632/adfl.33.1.29

Larsen -Freeman, D., \& Long, M. H. (2000). An introduction to second language acquisition research. Shanghai: Shanghai Foreign Language Education press.

Legg, R. (2009). Using music to accelerate language learning: An experimental study. Research in Education, 82(1), 1-12. http://dx.doi.org/10.7227/RIE.82.1

Li, X., \& Brand, M. (2009). Effectiveness of music on vocabulary acquisition, language usage, and meaning for Mainland Chinese ESL Learners. Journal of Contributions to Music Education, 36, 73-84.

Medina, S. L. (1993). The effect of music on second language vocabulary acquisition. National Network for Early Language Learning, 6(3), 1-11.

Mora, C. F. (2000). Foreign language acquisition and melody singing. ELT Journal, 54, 146-152. http://dx.doi.org/10.1093/elt/54.2.146

Murphey, T. (1992). Music and song. Oxford: Oxford University Press.

Richards, J. (1969). Songs in language learning. TESOL Quarterly, 3(2), 161-174. http://dx.doi.org/10.2307/3586103

Salcedo, C. S. (2002). The effects of songs in the foreign language classroom on text recall and involuntary mental rehearsal. Doctoral dissertation, Louisiana State University.

Salcedo, C. S. (2010). The effects of songs in the foreign language classroom on text recall, delayed text recall and involuntary mental rehearsal. Journal of College Teaching \& Learning, 6, 19-30. http://dx.doi.org/10.19030/tlc.v7i6.126

Shoebottom, P. (2013). The importance of vocabulary. Retrieved from http://esl.fis.edu/parent/advice/vocab.htm Thornbury, S. (2002). How to teach vocabulary. Harlow: Longman.

Williams, K. (1997). Expressive vocabulary test. Circle Pines, MN: American Guidance Services.

Williams, M., \& Burden, R. L. (1997). Psychology for language teachers. Cambridge: CUP.

Yuliana, Y. (2003). Teaching English to young learners through songs. K@ta, 5(1), 62-66. 